\title{
МЕТОДИКА
}

УДК 371.134:811.162.2(07)

Валентина Коваль

(Умань, Україна)

\section{ПЕДАГОГІЧНІ УМОВИ ФОРМУВАННЯ ПРОФЕСІЙНОӤ КОМПЕТЕНТНОСТІ МАЙБУТНІХ УЧИТЕЛІВ-ФІЛОЛОГІВ}

У статті визначено та проаналізовано педагогічні умови формування професійної компетентності майбутнього вчителя-філолога, зокрема виокремлено такі педагогічні умови, як організація у вищих навчальних закладах компетентнісно спрямованого навчання, вироблення у студентів лінгводидактичних стратегем $i$ мовленнєво-поведінкової стратегії майбутньої професійної діяльності, створення позитивної мотивації у студентів до формування особистісних $і$ професійних якостей.

Ключові слова: педагогічні умови, професійна компетентність, організаційнометодична система, компетентнісно спрямоване навчання, лінгводидактичні стратегеми.

Коваль В. Педагогические условия формирования профессиональной компетентности будущих учителей-филологов.

B cтатье определены и проанализированы педагогические условия формирования профессиональной компетентности будущего учителя-филолога, $в$ частности выделены следующие педагогические условия: организация в высших учебных заведениях компетентно направленного обучения, выработка у студентов лингводидактических стратегем и речевой поведенческой стратегии будущей профессиональной деятельности, создание положительной мотивации у студентов к формированию личностных и профессиональных качеств.

Ключевые слова: педагогические условия, профессиональная компетентность, организационно-методическая система, компетентно направленное обучение, лингводидактические стратегемы.

Koval V. Pedagogical conditions of formation of professional competence of future teachers of philology.

The article defines and analyzes pedagogical conditions of formation of professional competence of the future teacher-philologist, particularly singled out the following pedagogical conditions as an organization in higher education competence directed education, the development of the student's linguodidactic strategies and speech and behavioral strategies for future professional activity, creating positive motivation in students the formation of personal and professional qualities.

Keywords: pedagogical conditions, professional competence, organizational and methodical system, competence directed education, linguodidactic strategies. 
XXI століття висуває нові вимоги до підготовки вчителя загальноосвітньої школи. Це не панацея, а єдиний шлях успішного входження України в європейський та світовий освітній простір. Такого вчителя готує вищий навчальний заклад, а це означає, що система навчання у вищій школі має бути переглянута з позицій їі змісту, нових форм і методів підготовки майбутніх учителів-філологів. На цих аспектах наголошено в Державній національній програмі «Освіта» (Україна XXI століття), Законі України «Про вищу освіту», Національній доктрині розвитку освіти та ін.

Формування професійної компетентності майбутніх учителівфілологів має бути спрямований на модернізацію на всіх рівнях змісту освіти, форм, методів і технологій навчання; впровадження акмеологічних та аксіологічних засад у професійній підготовці педагогічних кадрів; зміцнення інституту сім'ї; збереження національних традицій і цінностей; забезпечення якості освіти на всіх рівнях відповідно до європейських та національних стандартів; формування методологічної культури педагогічних кадрів; забезпечення інтеграції науки і практичної педагогічної діяльності.

У зв’язку з цим українські лінгводидакти по-новому підходять до розуміння місця й ролі вчителя-філолога, способів досягнення поставленої мети (методи, прийоми, засоби, форми), що дозволить вивести на якісно вищий рівень підготовку фахівців у галузі мови й літератури, здатних не тільки до вузькоспеціального вирішення внутрішніх чи зовнішніх філологічних проблем, але й до компаративного аналізу лінгвопредставлення концептосфер різних етносів.

Для виконання таких завдань необхідний комплекс педагогічних умов, яким належить особлива роль у навчальному процесі. Педагогічні умови виступають у вигляді комплексу практично реалізованих в освітньому процесі ВНЗ заходів, спрямованих на формування професійної компетентності, реалізацію методики фахового становлення компетентності майбутніх учителів-філологів.

«Умова» вважається «філософською категорією, в якій відображаються універсальні відношення речі до тих факторів, завдяки яким вона виникає та існує» [26, с. 482]. «Умови» трактуються як «необхідні обставини, особливості реальної дійсності, які уможливлюють здійснення, створення, утворення чого-небудь або сприяють чомусь» [7, c. 1295].

Стає очевидним, що у довідниковій літературі поняття «умова» має неоднозначне визначення. Умова тлумачиться як «правило, що забезпечує нормальну роботу будь-чого; як філософська категорія, яка виражає ставлення предмета до оточуючих його явищ, без яких він існувати не може» [4, с. 39]; як «фактор» [9], як сукупність об'єктів речей, процесів, 
відношень, необхідних для виникнення, існування або зміни зумовленого об'єкта [14]; як сукупність перемінних природних, соціальних, зовнішніх та внутрішніх впливів, що позначаються на фізичному, психічному, моральному розвитку людини, ii поведінці; вихованні й навчанні, формуванні особистості [22]; як «необхідна обставина, яка робить можливим здійснення, створення, утворення чого-небудь або сприяє чомусь» [17, с. 15].

Узагальнюючи різні підходи до визначення категорії «умова», ми будемо дотримуватися думки, що «умови» $\epsilon$ сукупністю об' єктів, властивостей і відносин, які сприяють реалізації наявних можливостей.

У межах нашого дослідження важливо 3'ясувати семантику поняття «педагогічні умови».

«Педагогічні умови» визначаються як «обставини, від яких залежить та відбувається цілісний продуктивний педагогічний процес професійної підготовки фахівців, що опосередковується активністю особистості, групою людей» [25, с. 243].

В. Андреєв [1], I. Ареф’єв [3], С. Хатунцева [27] розглядають педагогічні умови як результат відбору й застосування елементів змісту, методів, а також організаційних форм навчання для досягнення конкретних цілей і є запорукою розвитку та вдосконалення педагогічного процесу.

Закономірно, що результативність роботи будь-якої системи залежить насамперед від того, в яких умовах вона функціонує. Для педагогічних систем адекватний вибір умов здатний забезпечити не тільки стійкі показники окремих педагогічних результатів, а й стабільне покращення якості освіти загалом.

Тож педагогічними умовами визначаємо сукупність заходів педагогічного процесу, які, 3 одного боку, забезпечують досягнення студентами необхідного рівня сформованості професійної компетентності, а $з$ другого - сприяють підвищенню ефективності цього процесу.

До таких умов зараховуємо:

- організацію у вищих навчальних закладах компетентнісно спрямованого навчання;

- вироблення у студентів лінгводидактичних стратегем і мовленнєвоповедінкової стратегї майбутньої професійної діяльності;

- створення позитивної мотивації у студентів до формування особистісних та професійних якостей.

Перша педагогічна умова (організація у вищих навчальних закладах компетентнісно спрямованого навчання) узгоджується 3 основними положеннями Закону України «Про засади державної мовної політики» (2012): 
- проведення ефективної мовної політики, що сприятиме дієвій реалізації стратегії мовної освіти, стійка увага суспільства до загального рівня мовної культури населення;

- консолідація зусиль науковців, педагогів, батьків, спрямованих на розв'язання актуальних завдань сучасної гуманітарної освіти;

- активізація діяльності громадських педагогічних організацій з метою підвищення уваги суспільства до проблем мовної освіти;

- оновлення Концепції мовної освіти в Україні, що дасть змогу піднести мовну освіту на якісно новий рівень; сприятиме формуванню мовної особистості учня / студента; забезпечить кожному учневі і студенту вільне володіння державною, рідною, іноземними мовами; закладе підгрунтя для вдосконалення власного мовлення впродовж життя;

- упровадження перспективних освітніх технологій - особистісно зорієнтованих, інформаційних, технологій саморозвитку, життєтворчості, партнерської співпраці;

- удосконалення діагностичних засобів відповідно до змісту нової Концепції для визначення рівнів навчальних досягнень учнів / студентів з мов, а також виявлення умов, які позитивно впливають на кінцеві результати засвоєння мов;

- удосконалення змісту мовної освіти у вищих навчальних закладах, що забезпечить формування особистості вчителя-словесника, здатного впроваджувати новітні ефективні технології опанування мовою й мовленням, культурою мовлення, а також мовної особистості спеціалістів різних профілів;

- створення при педагогічних вищих навчальних закладах та інститутах післядипломної педагогічної освіти лабораторій наукового дослідження проблем навчання мов у школі, що сприятиме поєднанню навчальної та науково-дослідної роботи, залученню студентів до науково-пошукової діяльності педагога;

- створення Національного центру мовної освіти України 3 метою координації дій щодо поліпшення якості мовної освіти, поєднання новітніх наукових досліджень 3 практичною діяльністю [12].

Ефективна реалізація Закону України «Про засади державної мовної політики» (2012) передбачає системний підхід: оновлення навчальнометодичного забезпечення, удосконалення професійної майстерності учителів/викладачів, планомірне і цілеспрямоване управління освітою, залучення до розв'язання проблем мовної культури громадських організацій і суспільства загалом.

Центральне місце в успішній реалізації завдання взаємного визнання уніфікованих кваліфікацій і ступенів шляхом досягнення суб'єктами навчання визначеної системи компетенцій поряд зі структуруванням 
освіти посідає організація у вищих навчальних закладах компетентнісно спрямованого середовища. Сучасна освітня практика вимагає адаптації до нових ціннісних установок освіти, які постійно змінюються, та розробки i прийняття нової освітньої парадигми. Саме компететнісно спрямоване середовище допомагає втілити в життя ідею саморозвитку освітніх систем, сформувати особистість, здатну орієнтуватися в розмаїтті протиріч сучасного світу, визначати свій власний шлях саморозвитку, самонавчання і самовизначення у професійній кар'єрі.

Досвід впровадження освітніх та педагогічних інновацій у компететнісно спрямоване середовище підтверджує, що для вдосконалення навчального процесу у вищих навчальних закладах ставляться такі основні завдання:

1) технологічна, організаційна та компетентнісно спрямована модернізація навчального процесу;

2) удосконалення змісту програм і курсів;

3) стажування професорсько-викладацького складу ВН3 на основі компетентнісного підходу.

Перше завдання можна розв'язати через упровадження стандартних інноваційних технологій і методик, що адаптуються до вимог та рівня компетентнісно-організаційного забезпечення в конкретному навчальному закладі.

Реалізація другого завдання забезпечується шляхом конструювання змісту освіти відповідно до наукових, технологічних та практичних досягнень науки і практики.

Третій аспект залежить від здатності викладача опанувати методикою та від його психолого-педагогічної готовності до прийняття відповідних змін. Впровадження у навчальний процес нових педагогічних та інформаційних технологій - це не заміна однієї «поганої» технології на іншу «добру», а насамперед перехід вищого навчального закладу до нового якісного стану, який, власне, потребує перепідготовки викладачів, оскільки частка всіх інноваційних процесів залежить від творчої активності педагогічного колективу. Активність впровадження технологічних інновацій у вищому навчальному закладі, їх дієвість значною мірою залежать від становлення суб'єктності педагога, тому що особистість викладача та його світоглядні позиції безпосередньо позначаються на змісті освіти.

Перша педагогічна умова передбачає реалізацію діяльніснопрактичного компонента моделі формування професійної компетентності майбутніх учителів-філологів:

- грунтовну методологічну підготовку, оволодіння дидактикою навчання майбутніх учителів, технологіями взаємодії, які найбільшою мірою сприяють особистісному професійному розвитку всіх учасників 
педагогічного процесу. Необхідними чинниками такої підготовки вважаємо високий освітній рівень студентів, різноманітність форм i методів навчання, пізнавальних та культурних потреб; партнерство як форма взаємодії в процесі навчання;

- спрямованість навчально-виховного процесу на майбутню професійну діяльність;

- забезпечення послідовності, цілісності і неперервності етапів розвитку професійної компетентності, на чому акцентують увагу Б. Андрієвський [2], Г. Жуков [11], Н. Ничкало [19], І. Раченко [24]. Неперервність процесу формування професійної компетентності забезпечується превентивною підготовкою вчителів-філологів, яка здійснюється 3 метою визначення рівня їх психологічної готовності до професії та рівня відповідності вимогам; проведення семінарів, тренінгів, інших форм фахового розвитку, що сприяють формуванню професійного способу мислення майбутніх учителів-словесників;

- співпраця викладача і студента сприяє взаємозбагаченню, обміну думками, готовності до професійного діалогу, активності учасників навчального процесу, прагненню до спільної діяльності. Така співпраця забезпечується самостійним і свідомим вибором мети, цінностей, способів навчання 3 урахуванням особистісних запитів та суспільних вимог до освітньо-професійних програм;

- реалізація індивідуальних можливостей кожного студента здійснюється в умовах усвідомлення диференціації навчання як множинності та варіативності індивідуальних і колективних підходів до реалізації змісту освіти й особистісно орієнтованого навчання, що допоможе майбутнім вчителям швидше адаптуватися до соціальних вимог дійсності та реалізувати свій особистісний потенціал;

- розвиток майбутніх учителів-філологів як творчих, ініціативних фахівців забезпечується у процесі залучення студентів до науководослідної роботи, що сприяє вихованню вимогливості до себе, удосконаленню вміння аналізувати та синтезувати процеси і явища, які відбуваються в галузі філології та суспільстві загалом, наповненню їх діяльності прагненням визначати сутність явищ, обирати ефективні засоби розв'язання професійних проблем, експериментувати, здійснювати самоаналіз і самооцінку. Дослідники вважають самооцінку складовою частиною структури навчальної діяльності, функція якої полягає в перевірці адекватності способів дії відповідно до поставлених завдань [6]; самоконтролю, його заключного етапу, який дозволяє визначити тим, хто навчається, міру засвоєння способів дій і власних можливостей [16]; внутрішньою основою для прийняття навчального завдання, що, виконуючи регулятивну функцію, бере на себе роль мотиву навчальної діяльності [13]; показником того, як «індивід оцінює себе у відношенні до 
якоїсь специфічної цінності» [15]; судженням особи про міру наявності в неї тих чи інших якостей, властивостей відповідно до певного еталона, зразка; вияв оцінного ставлення людини до себе [20].

Самооцінка відіграє значну роль в управлінні власною поведінкою, виступає суб' єктивною основою для визначення рівня претензій, тобто тих завдань, що особистість ставить перед собою в житті і реалізувати які вона вважає себе спроможною. Самооцінка дозволяє вчасно відмовитися від початої дії, якщо людина зрозуміла, що ця дія не результативна і, тим більше, помилкова. Адекватне чи неадекватне ставлення до себе веде або до гармонійності духу, що забезпечує розумну впевненість у собі, або до постійного конфлікту.

Володіння основами науково-дослідної діяльності забезпечує розвиток творчості майбутніх учителів-філологів, який сприяє:

- залученню студентів до роботи у проблемних групах, де обговорюються та засвоюються теоретичні положення i методичні принципи наукової проблеми, над якою працює певна група;

- підвищенню загальнокультурного рівня майбутніх учителівфілологів -забезпечується різноманітними інтересами, глибокими i грунтовними знаннями проблем філології, психології, педагогіки, методики, управління. Розвиток загальнокультурного рівня вчителівфілологів сприяє і розвитку їх професійної компетентності. Практикою підвищення загальнокультурного рівня майбутніх учителів-філологів $\epsilon$ моніторингові дослідження [23];

- узагальненню та вивченню практичного досвіду - здійснюється завдяки особистому досвіду (як життєвому, так і професійному). Саме це підкреслює цінність процесу навчання, різних аспектів практичного досвіду, дозволяє виявити суперечності та невирішені проблеми;

- використанню інтерактивних технологій, завдяки яким розвиваються компетентності особистості. Засобами забезпечення інтерактивного навчання $\epsilon$ партнерська взаємодія учасників навчально-виховного процесу, взаємозбагачення, обмін думками, активна співпраця з іншими учасниками навчального процесу, готовність до професійного діалогу. Інтерактивні технології реалізуються у формах ділових та рольових ігор, «методичного калейдоскопа», «круглих столів», «скарбнички вдалих педагогічних прийомів», «аукціону методичних ідей» тощо.

Другою педагогічною умовою вважаємо вироблення у студентів лінгводидактичних стратегем i мовленнсво-поведінкової стратегії майбутньої професійної діяльності.

У процесі своєї професійно-педагогічної діяльності майбутній фахівець повинен уміти проектувати і стратегічно моделювати навчальну діяльність учнів для засвоєння рідної мови як основного засобу розуміння української етнокультури та іноземної мови як засобу міжкультурної 
комунікації. Водночас учитель-філолог здатний брати участь у міжкультурній взаємодії, спираючись на свої лінгводидактичні знання.

У нашому дослідженні лінгводидактичні стратегеми трактуються як здатність фахівця встановлювати багатопланові асоціативні зв'язки у процесі розуміння, особистісного осмислення i творчого освоєння побаченого, почутого або прочитаного, письмового або усного мовного матеріалу, використовуючи індивідуальні засоби виразності. Пошук ефективних лінгводидактичних стратегем вирішення професійних завдань пов'язаний із використанням засобів вербальної і невербальної виразності пізнавально-комунікативної діяльності вчителя. Аргументуємо вибір цієї умови формування професійної компетентності майбутнього вчителя також тим, що в майбутній професійній діяльності стратегеми дозволять спеціалісту орієнтуватися в культурному і міжкультурному просторі на більш високому особистісно осмисленому творчому рівні.

Застосування лінгводидактичних стратегем у професійнопедагогічній діяльності грунтується на використанні вчителямифілологами оптимальних способів уведення інформації навчального матеріалу, враховуючи принципи комунікативності та творчої самоактуалізації, які можна реалізувати тільки з опорою на метод проектів та ігрові технології. Адже саме за допомогою ігрових вправ і методу проектів у студентів формується мотивація оволодіння професійною компетентністю, і саме такий вид роботи забезпечить студентам досвід координації дій у вирішенні спільних навчальних завдань.

Окремі лінгвісти і методисти $[18 ; 21]$, які вивчають проблеми міжкультурної комунікації, поряд із терміном «лінгводидактичні стратегії» пропонують використовувати термін «мовленнєво-поведінкові стратегії». Вивчаючи принципи формування міжкультурної компетентності, Г. Слізарова звертається до принципу мовленнєвоповедінкових стратегій як одного 3 основних. Ці стратегії дослідниця розуміє як магістральну лінію поведінки, яка грунтується на знаннях про культурні універсалії, про власне культурні цінності та способи їх відображення в поведінці, на аналогічних знаннях, що стосуються культури мови, на знаннях про можливий конфлікт або взаємодію культур, на знаннях про способи медіації під час такої взаємодії, мотивації до набуття знань, на емпатичному відношенні до подій та до залучених у них індивідів, на вміннях динамічно втілити всі ці знання й відношення в актуальні дії в ситуаціях спілкування [10, с. 203].

У навчальному процесі принцип мовленнєво-поведінкових стратегій може втілюватися шляхом послідовного вивчення культурних універсалій тими способами, якими вони відображаються в моделях вербальної i невербальної поведінки. Проте набагато ефективніше відстежувати комбінований, взаємозалежний прояв культурних універсалій у реальній 
дійсності і виробляти вміння враховувати їх у власній поведінці й поведінці співрозмовників.

Для практичної реалізації вироблення у студентів педагогічних ВН3 лінгводидактичних стратегем i мовленнєво-поведінкової стратегії викладач повинен:

- організовувати спільну (викладач - студенти) навчальну комунікативну діяльність;

- забезпечувати активну взаємодію студентів між собою;

- організовувати міжфакультетську i міжвишівську проектну діяльність студентів;

- відбирати для студентів автентичні текстові матеріали та розробляти відповідні методичні рекомендації;

- забезпечувати зміну напруження й релаксації у процесі навчання (під час роботи над проектом чи в ігровій ситуації);

- формувати професійні вміння й навички в умовах, максимально наближених до природної комунікації в ході сюжетно-рольових ігор;

- розробляти спільно зі студентами ефективні педагогічні стратегії в контексті професійної діяльності шляхом створення авторських технологій, адаптаційних програм і методичних систем.

Результатом такої діяльності викладача стане:

- обмін особистісними смислами створення культурного спілкування, спрямованого на засвоєння різноманітних елементів освітнього простору;

- наближення студентів до умов реального автентичного спілкування з носіями іншої культури;

- залучення студентів до узагальнення й обміну потенціалами інноваційної діяльності зі студентами філологічних факультетів інших BH3;

- подальше застосування студентами мовного матеріалу під час шкільних практик;

- забезпечення студентам можливості максимально використовувати пам'ять, уяву і творчі здібності;

- сприйняття студентами процесу навчання як моделі реального міжкультурного спілкування;

- складання, опис та аналіз студентами тексту взаємодії з майбутніми учнями в педагогічному процесі внаслідок умілого використання індивідуальних лінгводидактичних стратегем.

Друга педагогічна умова передбачає реалізацію когнітивно-творчого компонента моделі формування професійної компетентності майбутніх учителів-філологів.

Отже, розвиток у студентів професійної компетентності спрямований на пошук майбутніми фахівцями ефективних лінгводидактичних стратегем вирішення професійних завдань 3 використанням засобів 
вербальної і невербальної виразності пізнавальної та комунікативної діяльності вчителя. Методико-технологічним інструментом формування професійної компетентності є імітаційно-ігрові методи та метод проектів, які забезпечують більш високий, порівняно з традиційною методикою, ступінь мотивації, пізнавальної самостійності студентів, а також дозволяють перевести студента 3 позиції об'єкта на рівень суб'єкта навчальної діяльності, що підвищує якість мовної та професійної підготовки майбутніх учителів.

Створення позитивної мотивації у студентів до формування особистісних та професійних якостей $є$ третьою педагогічною умовою, що реалізується мотиваційно-ціннісним компонентом моделі формування професійної компетентності майбутніх учителів-філологів. Ця умова $є$ зовнішньою обставиною, що сприяє формуванню професійних та особистісних якостей студентів-філологів.

Сучасній школі потрібен учитель, якому властива інша типологічна структура особистості. Суб'єкт має постійно змінюватися, бути лабільним, здатним саморозвиватися i самовизначатися в різних ситуаціях, відкритим до соціального замовлення освіти (суб'єкт, який розуміє своє професійне призначення, сприймає педагогічну діяльність як важливий пріоритет, спроможний і готовий до постійного перенавчання i поновлення знань, умінь і навичок щодо організації навчальної діяльності учнів).

Науковці виділяють три обов'язкових аспекти для засвоєння будьякої педагогічної інновації: рефлексія, розуміння та особистісна підготовленість. Важливо мати на увазі, що саме рівень особистісної підготовленості $є$ головною перешкодою впровадженню у навчальний процес нових технологій.

Діяльність суб' єкта навчання характеризується такими ознаками:

- здатністю до рефлексії, морального вибору у проблемних ситуаціях;

- усвідомленням власної значимості для інших людей, відповідальності за результати діяльності, причетності до відповідальності за явища природної і соціальної дійсності;

- спроможністю не тільки привласнювати світ предметів та ідей, але й виробляти їх, перетворювати, творити нові, самостійно визначати їх у необхідних випадках;

- незалежністю поглядів, переконань, мотивів;

- спрямованістю на реалізацію «САМО...» - самоосвіти, самооцінки, самоаналізу, саморозвитку, самовизначення, самодетермінації тощо;

- наявністю важливих індивідуально-процесуальних характеристик (різнобічність умінь, самостійність, творчий потенціал тощо), унікальністю, неповторністю, що $є$ основою для плідних міжсуб'єктних відносин і що стимулює прагнення до взаємодії, 
співробітництва, спілкування. У результаті самовизначення людина вибудовує систему смислів, смислове поле або внутрішній смисловий простір. Два процеси - осмислення (наділення цінностей сутністю) та усвідомлення (формулювання сутностей у цінності) поєднуючись, творять простір суб'єктності людини або іiі цінніснозначущу сферу. Вона i $\epsilon$ справжнім середовищем i продуктом саморозвитку людини.

Усе це стане реальним при позитивній мотивації студента до формування особистісних професійних якостей.

Мотивацію можна вважати однією зі складових професійної компетентності. Н. Бородіна переконана, що внутрішня мотивація $\epsilon$ найбільш продуктивною у навчальній діяльності студентів, оскільки вона грунтується на зацікавленості студентів тим, що є важливим і необхідним для людини (прагнення до знань, розширення власного кругозору, поглиблення та систематизація знань, покращення результатів своєї діяльності, підготовка до фахової діяльності). Крім внутрішніх мотивів, вона виокремлює і деякі зовнішні: мотиви самоідентифікації, мотиви виконання обов' язків, авторитету, незалежності, самостійності [5, с. 42].

Таким чином, у зовнішніх мотивах пізнавальна діяльність виступає засобом досягнення мети, а у внутрішніх - вона сама є метою.

Значення того чи іншого мотиву залежить від віку студентів, рівня їхньої вихованості, розумових здібностей, а також професійної майстерності викладача, суспільних, соціальних умов, у яких проходить навчання.

Велику роль у процесі мотивації відіграє пізнавальний інтерес, який є однією 3 головних умов ефективності навчання та його організації. В. Галузяк, М. Сметанський та В. Шахов виокремлюють такі умови успішного формування пізнавального інтересу: 1) залучення студентів до самостійного пошуку і набуття нових знань; 2) навчання повинно бути важким, але посильним; 3) новий матеріал необхідно пов' язувати з раніше засвоєним; 4) різноманітна навчальна діяльність; 5) яскравість та емоційність навчального матеріалу, емоційність викладання вчителя; 6) інтерес до роботи студентів має підкріплюватись постійними перевірками й оцінюванням [8, с. 107].

Наріжним каменем формування позитивної мотивації вважають ефективний індивідуально орієнтований стиль спілкування педагога i студента. Саме взаємно зацікавлене, товариське спілкування сприяє індивідуалізації процесу фахового розвитку студентів.

Виконання цієї вимоги завжди залежало від своєрідності освітньої системи, від педагога, його фахової компетентності та інших індивідуально-психологічних характеристик, а також від індивідуальних особливостей студентів. Існує можливість враховувати індивідуальний 
розвиток не кожного окремого студента, а групи студентів, що володіють подібними особливостями. Індивідуалізація фахового розвитку сприяє також формуванню в студентів індивідуального стилю своєї навчальної діяльності. Допомогти студентам сформувати індивідуальний стиль навчальної діяльності - означає допомогти їм знайти свої специфічні, оптимальні засоби пристосування до навчальних ситуацій тощо. Необхідно створити таке компетентнісно спрямоване середовище, у якому студенти могли б розвивати свої здібності, захоплення, творчий потенціал, реалізовувати потреби та інтереси.

Реалізація цієї умови забезпечується шляхом використання таких форм i методів навчально-виховної роботи, як розповідь, бесіда, написання творів-роздумів, зустрічі з учителями-практиками, складання «Портрета сучасного вчителя-філолога», у ході яких значна увага приділялася би побудові суб'єкт-суб'єктних стосунків на основі демократичних принципів взаємодії викладачів і студентів.

Процесуальний аспект реалізації педагогічних умов формування професійної компетентності майбутніх учителів-філологів передбачає зміну мотивації набуття i застосування знань, отриманих у процесі навчання: iз засобів добування нових знань у засіб самореалізації i самоствердження через використання системних знань у шкільній практиці. Для цього процес навчання необхідно побудувати як систему занять iз розв'язанням ситуативних задач. Такий підхід збагатить особистий досвід студентів та допоможе вирішити проблеми, пов'язані із взаємодією та спілкуванням у колективі.

Реалізація педагогічних умов сприятиме забезпеченню організаційнопедагогічного й психолого-педагогічного супроводу процесу формування професійної компетентності майбутніх учителів-філологів, удосконаленню їі методики.

Отже, у результаті проведеного дослідження визначено педагогічні умови формування професійної компетентності майбутніх учителівфілологів, до яких належать: організація компетентнісно спрямованого навчання у вищих навчальних закладах; вироблення у студентів лінгводидактичних стратегем i мовленнєво-поведінкової стратегії майбутньої професійної діяльності; створення у студентів позитивної мотивації до формування особистісних та професійних якостей.

\section{СПИСОК ВИКОРИСТАНОЇ ЛІТЕРАТУРИ}

1. Андреев, В. И. Педагогика : учебный курс для творческого саморазвития / Валентин Иванович Андреев. - 2-е изд. - Казань : Центр инновационных технологий, 2006. - 608 с. 
2. Андрієвський, Б. М. Реалізація концепції неперервної педагогічної освіти вимога часу / Б.М. Андрієвський // Актуальні проблеми розбудови національної освіти : зб. наук.-метод. праць. - Херсон : ХДПІ, 1997. - С. 14-17.

3. Арефьев, И. П. Подготовка учителя к профильному обучению старшеклассников / И. П. Арефьев // Педагогика. - 2003. - № 5. - С. 49-55.

4. Байша, К. М. Соціально-педагогічні умови морального виховання студентів у позанавчальній діяльності : дис. ... канд. пед. наук : 13.00.07 / Байша Кіра Миколаївна. - Херсон, 2000. - 193 с.

5. Бородіна, Н. С. Наукові засади професійного засвоєння лінгводидактичної термінології студентами філологічних документів : дис. ... канд. пед. наук : 13.00.02 / Бородіна Наталія Сергіївна. - Херсон, 2007. - 283 с.

6. Брунер, Дж. Психология познания / Джером Брунер. - М. : Прогресс, 1977. 404 c.

7. Великий тлумачний словник сучасної української мови / [авт.-уклад. Бусел В.]. - К. : Ірпінь : Перун, 2001. - 1440 с.

8. Галузяк, В. М. Педагогіка : навч. посіб. / В. М. Галузяк, М. І. Сметанський, В. І. Шахов. - 3-тє вид., випр. і допов. - Вінниця : Державна картографічна фабрика, 2006. - 400 с.

9. Гальперин, И. Р. Текст как объект лингвистического исследования / Илья Романович Гальперин. - М. : Наука, 1981. - 139 с.

10. Елизарова, Г. В. Культура и обучение иностранным языкам / Г. В. Елизарова. СПб. : Союз, 2001. - 291 с.

11. Жуков, Г.Н. Готовность к деятельности как социально-педагогическая категория: инновационный подход / Г. Н. Жуков // Образование и наука : известия Уральского научно-образовательного центра РАО. - 2000. - № 3(5). С. $176-180$.

12. Закон України «Про засади державної мовної політики»_від 03.07.2012 № 5929VI [Електронний ресурс]. - $\quad$ Режим доступу http://zakon4.rada.gov.ua/laws/show/5029-17/page.

13. Захарова, А. В. Генезис самооценки : дис. ... докт. психол. наук : 19.00 .01 / Захарова Аида Васильевна. - М., 1989. - 350 с.

14. Каспина, В. А. О методах воспитания и их классификации / В. А. Каспина // Советская педагогика. - 1970. - № 1. - С. 84-94.

15. Кон, И. С. Социология личности / Игорь Семенович Кон. - М. : Просвещение, 1967. - $234 \mathrm{c}$.

16. Кузьмина, 3. В. Исследование особенностей самооценки личности в условиях успеха и неудач : автореф. дис. на соискание ученой степени канд. психол. наук : спец. 19.00.01 «Общая психология, психология личности, история психологии» / 3. В. Кузьмина. - М., 1973. - 17 с.

17. Кутькина, О. П. Педагогические условия формирования медиакомпетентности будущих библиотечно-информационных специалистов : автореф. дис. на соискание ученой степени канд. пед. наук : спец. 13.00.08 «Теория и методика профессионального образования» / О. П. Кутькина. - Барнаул, 2006. - 23 с.

18. Мельникова, Л. В. Коммуникативно-ситуативные упражнения как средство развития ключевых компетентностей учащихся / Л. В. Мельникова, О. И. Рухмакова // Педагогічна скарбниця Донеччини. - 2004. - № 2. - С. 1316. 
19.Ничкало, Н. Г. Методичні проблеми безперервної професійної освіти / Н. Г. Ничкало // Психологічні проблеми безперервної професійної освіти : наук.- метод. зб. / гол. ред. І. А. Зязюн. - К. : Віпол, 1994. - С. 22-26.

20. Петров, А. Профессиональная компетентность : понятийно-терминологические проблемы / А. Петров // Alma mater. - 2004. - № 10. - С. 6-10.

21. Плужник, И. Л. Формирование межкультурной коммуникативной компетенции студентов гуманитарного профиля в процессе профессиональной подготовки : дис. ... канд. пед. наук : 13.00.01 / Плужник Ирина Ленаровна. - Тюмень, 2003. $-228 \mathrm{c}$.

22. Полонский, В. М. Словарь по образованию и педагогике / В. М. Полонский. М. : Высшая школа, 2004. - 512 с.

23. Радченко, А. Є. Моніторинг професійної педагогічної компетентності вчителя / А. С. Радченко // Управління школою. - 2005. - № 35-36. - С. 24-58.

24. Раченко, И. К. Как осуществить принцип стимулирования и перспективности в процессе организации педагогического труда / И. К. Раченко. - Пятигорск : [Б. и.], 1978. - 22 с.

25. Словник-довідник з професійної педагогіки / [авт.-упоряд. Семенова А. В.]. Одеса : Пальміра, 2006. - 272 с.

26. Український радянський енциклопедичний словник : в 3 т. / [авт.-уклад. Бабичев Ф. С.] - К. : Гол. ред. УРЕ, 1987. - Т. 3. - 736 с.

27. Хатунцева, С. М. Педагогічні умови адаптації викладача-початківця до професійно-педагогічної діяльності у вищому навчальному закладі : дис. ... канд. пед. наук : 13.00.04 / Хатунцева Світлана Миколаївна. - Х., 2004. - С. 9798.

Стаття надійшла 12.04.2016 року

УДК 372.315:808.5:811.161.2

Лариса Сауляк

(Умань, Україна)

\section{ЛІНГВІСТИЧНІ ОСНОВИ ТА ПСИХОЛІНГВІСТИЧНІ ЧИННИКИ НАВЧАННЯ РИТОРИКИ УЧНІВ СТАРШИХ КЛАСІВ ПРОФІЛЬНОЇ ШКОЛИ}

Засвоєння украӥнської мови вимагає від людини вмінь оцінювати ї̈ виражальні засоби $і$ користуватися ними в усному ц̆ писемному мовленні. Риторизація навчального процесу повинна йти від мовних одиниць до їх ролі в тексті, від спостереження над текстами-зразками до створення власного тексту. Уведення активних форм навчальної комунікації підвищує рівень мотивації мовленнєвої поведінки учнів.

Ключові слова: риторика, комунікативна підготовка, оратор, мовещь, мовна особистість,лінгвістичні основи, риторичний текст, культура мовлення.

Сауляк Л. Лингвистические основы и психолингвистические факторы обучения риторики учащихся старших классов профильной школь. 